\title{
Safety and Security Measures in Egyptian Hotels
}

\author{
Karam M. Ghazi \\ The High Institute of Tourism and Hotels, King Marriott, Alexandria, Egypt
}

\begin{abstract}
This study investigates safety and security measures from Egyptian hotel guests' viewpoint, through assessing the importance level and usage level of measuring and testing the gap between the importance and usage of measures. Using IPA Methodology, a stratified random sample was chosen. 500 questionnaires were randomly distributed to guests in 5-star hotels. The results indicated that the highly important and rarely usage measures are related to three dimensions; "Medical Preparedness, Guestroom Security, and Emergency Preparedness". Meanwhile, the less important and widely used measures are related to two dimensions; "Detectors, and Access Control". Additionally, there is a statistically significant gap between the importance level and the usage level of measures. Hence, there are opportunities for changes and improvements in Egyptian hotels.
\end{abstract}

Keywords: Safety, Security, Measures, IPA.

\section{Introduction}

Safety and security are important factors to tourists when choosing a destination and when selecting a hotel to stay at. The first aspect tourists consider is to be protected from risks and hazards. Unfortunately, the hotel and tourism industry is highly vulnerable in terms of safety and security threats. These threats are frequently in the forms of crimes, terrorism, natural disasters, health, and man-made hazards (Gill et al., 2002; Feickert et al. 2006; Enz, 2009; Homeland Security, 2010; Pizam, 2010; Prashyanusorn, et al., 2010; Kôvári, and Zimányi, 2011; Taillon, 2012; Wichasin, and Doungphummes, 2012; Boakye, 2012; Rittichainuwat, and Chakraborty, 2012; Rittichainuwat, 2006:2008:2011:2013; Chan, and Lam, 2013; AlBattat, and Som, 2013; Ahmed and Akther, 2013; Paraskevas, 2013; Lisle, 2013; Peter, et al., 2014; Yang, and Nair, 2014). This puts increasing pressure on hotel managers and planners to consider the impact of safety and security threats to the industry and develop more effective measures to stop or limit their negative impacts to protect hotel business and society in general. This emphasizes that hotels should upgrade their safety and security measures and procedures to make them harder targets against threats and hazards. Hotel management has been forced to review and revise safety and security measures accordingly (Pizam, 2010; Ghaderi, and Som, 2012; Mohammad et al., 2012; Nassar, 2012; AlBattat, and Som, 2013; Ahmed, and Akther, 2013; Peter, et al., 2014).

The problem of this study is the increasing of safety and security threats in recent years, which negatively affect the tourism and hospitality industry on a regular basis. Safety and security threats are now becoming more frequent, intense, and geographically diverse. The tragic incidents of the Egyptian Revolutions are recent reminders of the vulnerability of hotels to potential safety and security threats. From 25 January 2011 to date, Egypt experienced one of the worst political crises in its recent history. During this transition period, Egypt suffered a series of political instability events, violent incidents, terrorist attacks, clashes, labour strikes, and large protests. The violence was extensively and intensively reported in the international media. Many countries arranged to evacuate their citizens from Egypt and others warned their citizens about traveling to Egypt. Egypt was perceived as an unsafe and insecure destination for travel and tourism activities (Nassar, 2012; Mohammad et al., 2012). As a result of the Egyptian social and political instability, the international tourists, revenues, hotel occupancy rates, and employment levels dramatically decreased (Egyptian Ministry of Tourism, 2011; WTO, 2012; WTTC, 2013). 
The dramatic events associated with the Egyptian Revolutions from 2011 to date, will be remembered for some time and perhaps leading to tourists putting a greater emphasis on personal safety and security when choosing accommodation in the future. In the light of these tragic incidents, the purpose of this study is to investigate safety and security measures in the Egyptian hotel context through assessing both the importance level and performance level of measures from the perspectives of guests. Despite an increase in tourism safety and security literature in the past years, there is a lack of empirical research that evaluates the safety and security measures from guests' viewpoint in the hotel industry in general and in Egyptian hotels in particular.

\section{Study Objectives}

The purpose of this study is investigating safety and security measures in the Egyptian hotel context in order to enhance the understanding of safety and security measures and their effectiveness. The study focuses mainly on investigating the gap between hotel guests' perceived importance and their perceived performance of hotel safety and security measures. In particular, the study evaluates two related factors from guest's viewpoint 1) The level of importance of safety and security measures, 2) The level of performance (actual usage) of these measures. The specific objectives are to:

1. Assess the perceived importance of safety and security measures from Egyptian hotel guests' viewpoint.

2. Assess the perceived performance (usage) of safety and security measures from Egyptian hotel guests' viewpoint.

3. Assess the gap between the perceived importance and perceived usage of safety and security measures from Egyptian hotel guests' viewpoint.

\section{Study Hypothesis}

Using the Importance-Performance Analysis (IPA) methodology (Martilla and James, 1977), hotel safety and security measures are evaluated by using this proposition:

The hypothesis of this study is to test whether the performance (usage) level of safety and security measures are falling, meeting, or exceeding the importance level of these measures. It tests the gap between the importance level and usage level of security measures. Hence, the null and alternate of Hypothesis 1 are:

- $\mathbf{H}_{\mathbf{0}}$ - there will be no significant difference between the importance guest assigns to a certain measure and the performance level of this measure.

- $\mathbf{H}_{\mathbf{1}}$ - there will be a significant difference between the importance level assigns to a certain measure and level of performance of this measure.

\section{Literature review}

\section{Safety and Security Conceptualization}

The meaning of the terms safety and security varies considerably depending on the context in which it is being used and the researcher's discipline, leading to potential ambiguities. Linguistics and translation are responsible for some of the ambiguity (Line et al., 2006; Piètre-Cambacédès, and Chaudet, 2010). The Oxford Dictionary (2015) defined safety as "the condition of being protected from or unlikely to cause danger, risk, or injury," whereas defined security as "the state of being free from danger or threat". In tourism literature, the terms "safety" and "security" are usually used interchangeably as twin concepts. 
However, the two concepts differ in their focus (spotlight different angles) (George, 2003; Wichasin and Doungphummes, 2012; Mekinc, and Cvikl, 2013; Yang, and Nair, 2013). According to Sönmez and Graefe (1998), tourists' safety concern is a parallel concept to risk. Other studies (Maser and Weiermair, 1998; Reisinger and Mavondo, 2005) perceive safety and security as the subsets of risk. The Servqual Model suggested that security is "the freedom from danger, risk, or doubt" (Parasuraman, et al., 1985, p.47). This definition infers that security is the opposite of risk and danger, which means 'no risk' equals to secure. Hall, et al. (2004) stated, "for the tourism industry at least, security is now seen as more than just the safety of tourists" (p.3) and "the term security resonates with deep seated longings to be safe" (p.12). The above statements imply that safety and security are two distinctive but interrelated concepts (Yang, and Nair, 2013).

In hotel context, hotel safety refers to "protecting employees and customers within hotel property from potential injury or death" (Enz 2009), whereas hotel security goes beyond protecting employees and guests, to also include preserving guests' possessions and hotel property (Enz and Taylor, 2002; Enz, 2009). In other words, safety relates to human life while security deals with guests' and hotel's assets. Thus, safety issues deal with the effects of accidents, hazardous materials, and fire, whereas security issues involve such matters as theft and violent crime (Enz, 2009; Rittichainuwat, and Chakraborty, 2012; Rittichainuwat, 2013; Chan, and Lam, 2013). Hence, safety and security for this study focus on the protection of 1) guests, 2) employees, 3 ) and the hotel property.

Typology offers a better way to understand overall multidimensional constructs and help theorists achieve parsimony. As shown in Figure 1, the International Hotel and Restaurant Association classified safety and security issues in the hotel industry into broad categories of macro forces and micro forces (Olsen and Cassee, 1995). However, each of the safety and security events fitted under the dimensions of hotel safety and security offered by Olsen and Pizam (1999), as described in Figure 2. Pizam and Mansfeld (2006) identified four types of security incidents that are malevolent to the tourism industry: crime, terrorism, war, and civil/political turmoil. Safety, on the other hand, leans more towards health, accident, natural disaster, and other non-human induced incidents (Bentley, et al., 2001; Mansfeld and Pizam, 2006; Nardi and Wilks, 2007). Nevertheless, as an effect of globalization, the nature of tourism security has changed significantly from traditional issues of crime, terrorism, political stability, and national security to include health, social, and environmental issues (Hall et al., 2004; Yang, and Nair, 2013).

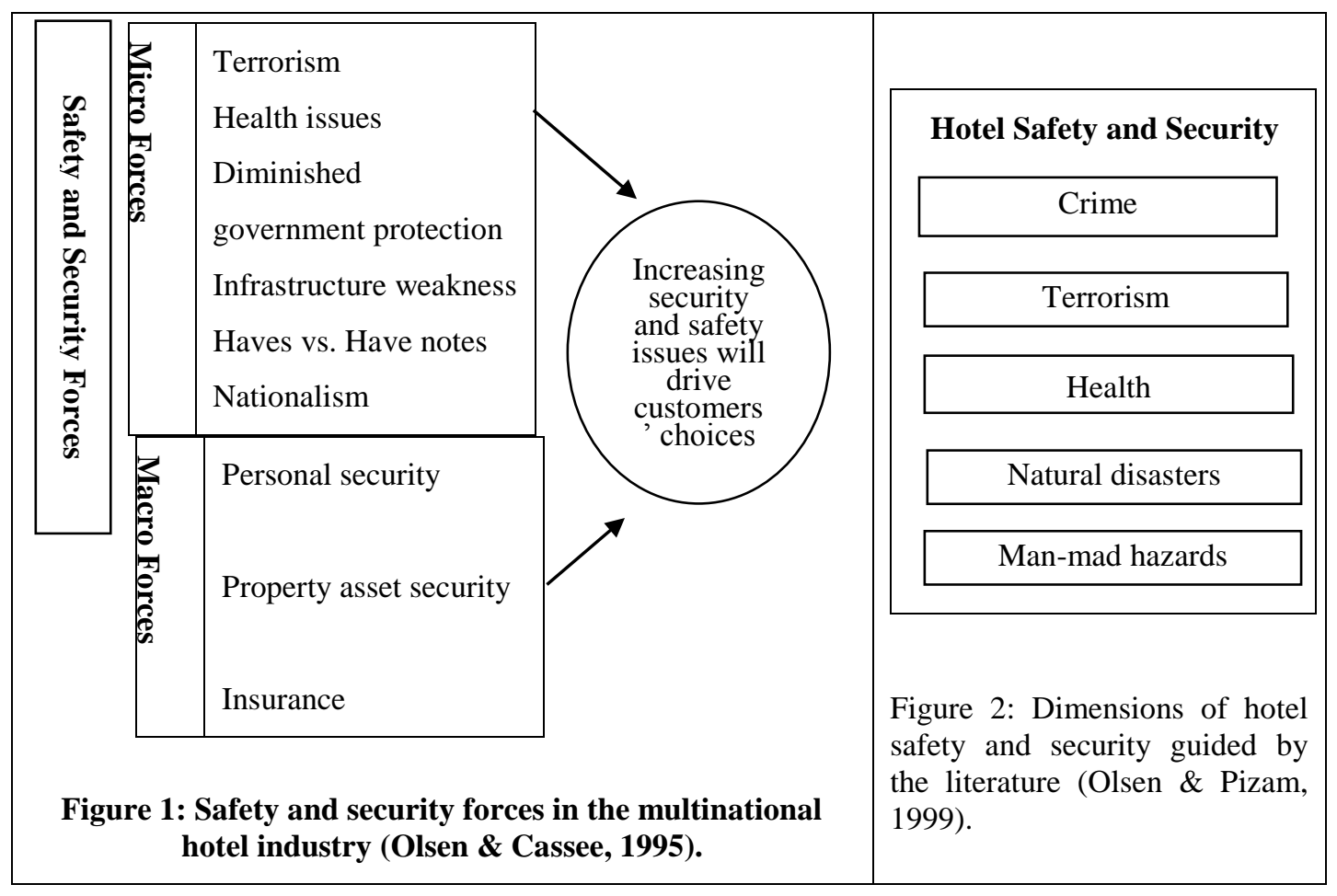


Table 1 Main difference between security and safety (Albrechtsen, 2003).

\begin{tabular}{|c|c|c|}
\hline & Security & Safety \\
\hline Causes & $\begin{array}{l}\text { an incident is most often a result of } \\
\text { one person or a group's well }\end{array}$ & $\begin{array}{l}\text { an incident is most often a result of } \\
\text { human behaviour in combination with } \\
\text { the environment }\end{array}$ \\
\hline Causes & often planned actions & often unplanned \\
\hline Causes & criminal acts & $\begin{array}{l}\text { criminal acts (working environment } \\
\text { act) }\end{array}$ \\
\hline Causes & mainly malicious acts & seldom, if ever, malicious \\
\hline Causes & $\begin{array}{l}\text { mainly deliberate acts with a wish } \\
\text { of a wanted output/consequence of } \\
\text { the act }\end{array}$ & $\begin{array}{l}\text { mainly deliberate acts without a wish } \\
\text { of a wanted output and accidental } \\
\text { incidents }\end{array}$ \\
\hline $\begin{array}{l}\text { threats/hazar } \\
\text { d }\end{array}$ & external \& internal human threats & internal human threats \\
\hline $\begin{array}{l}\text { threats/hazar } \\
\text { d }\end{array}$ & $\begin{array}{l}\text { threats are not always observable, } \\
\text { tangible and proximate }\end{array}$ & $\begin{array}{l}\text { hazards are observable, tangible and } \\
\text { proximate }\end{array}$ \\
\hline Loss & $\begin{array}{l}\text { loss is mainly related to physical } \\
\text { assets and information }\end{array}$ & $\begin{array}{l}\text { loss is related to human injuries/death } \\
\text { and reliability of industrial assets }\end{array}$ \\
\hline $\begin{array}{l}\text { Surroundin } \\
\text { gs }\end{array}$ & $\begin{array}{l}\text { reflects the state of society through } \\
\text { its structures, economical situation, } \\
\text { law-abidingness and moral }\end{array}$ & $\begin{array}{l}\text { includes physical and environmental } \\
\text { conditions - not only humans and } \\
\text { society }\end{array}$ \\
\hline Uncertainty & $\begin{array}{l}\text { High degree of uncertainty and low } \\
\text { degree of knowledge about threats }\end{array}$ & \\
\hline
\end{tabular}

Indeed, the tourism literature may fail to provide a clear and concise definition to the concepts "safety" and "security" in the hotel sector. Safety and security are basically synonyms and the difference is really small and not remarkable. Both are conditions where one is well protected and without risks. The basic ideas of safety and security are the same; both are protecting from hazards/threats creating safe/secure conditions (Hall et al., 2004; Mekinc, and Cvikl, 2013; Yang, and Nair, 2013). Nevertheless, there are some nuances that distinguish them, as shown in Table 1(Albrechtsen, 2003). One way to look at is that security is external factors that create the feeling of safety (Mekinc, and Cvikl, 2013). Some experts include safety as a category of security that focuses on the protection of guests and employees from injuries, whether from accidents or criminal activity (Enz, 2009). Following these distinctions, this study treats safety as a particular form of security that focuses on the protection of guests, employees, and the hotel from hazards/threats to create safe/secure conditions.

\section{Safety and Security Research}

Safety and security research in the hospitality and tourism industry began to appear in the1990s (AlBattat and Som, 2013; Chan , and Lam, 2013; Rittichainuwat, 2013). By studying 300 cases at worldwide tourism destinations, Pizam (1999) categorized the attributes of criminal and violent acts and analysed the differential effects of such attributes on tourism demand. Milman et al. (1999) investigated tourists' overall 
perceptions of safety in central Florida based on their perceptions of theme park safety, certain hotel physical security devices, the level of their education and the routine visibility of law enforcement officers in hotels. Tarlow, and Santana, (2002) examined tourism safety across cultural borders and offer the notion of a possible "safety continuum. George (2003) studied tourist perceptions of the safety and security of Cape Town based on personal factors, such as nationality and previous experience of crime. Boakye (2012) examined tourists' perspectives on issues concerning safety and security in Ghana. Mekinc, and Cvikl, (2013) analyzed causes for security and safety crises with direct or indirect impact on the tourist industry. Lisle, (2013) examined how responses to the targeting of tourists on Bali and Mombasa reinforced and reproduced the discourse of exceptionalism.

Other hospitality reactionaries investigate safety and security attributes and hoteliers' perceptions. For instance, Enz and Taylor (2002) surveyed 2,123 U.S. hotels and found that luxury and upscale hotels and airport and urban hotels possess a wider array of safety features than small, economy, and resort hotels. Similarly, Enz (2009) surveyed 5,487 U.S. hotels on their safety and security features and found that luxury and upscale hotels, newer hotels, larger hotels, and those located in urban and airport locations have the highest safety and security features than hotels located in small towns and resorts. In a study of 930 hotel guests, Feickert, et al. (2006) found relatively high acceptance of certain security measures, along with a willingness to pay extra for some of them. Respondents younger than forty were both more likely to accept stringent security measures and more willing to pay for them. Women were also more supportive of strong security measures than were men. Hilliard and Baloglu (2008) surveyed 100 U.S. meeting planners and found that meeting planners are most concerned with visible safety features, which influence their overall perceptions of a hotel's servicescape. Rittichainuwat, and Chakraborty, (2012) explored perceived importance of safety and security measures from the perspectives of tourists and service providers in Thailand. Rittichainuwat, (2013) assessed tourists' perceptions toward overt safety measures. Ahmed, and Akther, (2013) examined the consequences of terrorism for tourism with particular reference to the hotel industry and the case of Bangladesh. Homeland Security (2010) provided protective measures guide for the U.S. lodging industry. Paraskevas (2013) presented a six-step baseline anti-terrorism strategy for hotels to take at both low and high-risk levels.

Gill et al. (2002) studied the role of security managers in the UK hotel industry. Groenenboom and Jones, (2003) reported the findings of in-depth interviews with security managers from some of London's top hotels. Ling and Zheng (2008) analysed the intrinsic paragenesis is between hotel security systems and the support ability of science and technology. Su (2009) analysed the principle of dealing with emergencies and misunderstandings of emergency management. Pizam (2010) found that $30 \%$ of U.S. hotel general managers admitted that they had done nothing with regard to security procedures, and more than half thought that their security was sufficient. Peter et al. (2014) investigated the attitudes of hotel managers and staff to risk management prior to the event in New Zealand. Chan (2004) clearly showed that gaps might exist between the perceptions of hotel management and hotel guests and that these gaps might affect guest satisfaction. Similarly, Chan, and Lam, (2013) investigated the gap between hotel safety and security managers' and hotel guests' perceptions of the relative importance of safety and security facilities. However, no studies have investigated the gap between importance and performance of safety and security measures from hotel guests' viewpoint.

\section{Study Rationale}

\section{Hotels Vulnerability to Safety and Security Threats and Hazards}

Hotel properties generally present greater vulnerabilities with respect to safety and security threats. These threats are frequently in the forms of crimes, terrorism, natural disasters, health, and man-made hazards (Gill et al., 2002; Feickert et al. 2006; Enz, 2009; Homeland Security, 2010; Pizam, 2010; Prashyanusorn, et al., 
2010; Kôvári, and Zimányi, 2011; Taillon, 2012; Wichasin, and Doungphummes, 2012; Boakye, 2012; Rittichainuwat, and Chakraborty, 2012; Rittichainuwat, 2006:2008:2011:2013; Chan, and Lam, 2013; AlBattat, and Som, 2013; Ahmed and Akther, 2013; Paraskevas, 2013; Lisle, 2013; Peter, et al., 2014; Yang, and Nair, 2014). The reasoning behind this can be five-fold:

1. Hotels have a long history of being a "soft target" environment for safety and security threats (Enz, and Taylor, 2002; Enz, 2009; Homeland Security, 2010; AlBattat, and Som, 2013; Chan, and Lam, 2013; Paraskevas, 2013; Lisle, 2013; Peter, et al., 2014). Hotel as a working environment have become an easy target because of several factors, including open access with 24 hours a day, many public and multiple access points, parking lots, and encounters with strangers and foreigners. Hotels may be integrated with other facilities (e.g., malls, casinos, convention centers, meeting rooms, marinas, and airports) which have its own site- and situation-specific vulnerabilities. Furthermore, hotels have become vulnerable on account of their brand names, location, and their profile guests that include foreign tourists and hence attract the attention of National and International media on the happenings. Moreover, it is often difficult to distinguish among guests, legitimate visitors, and people who are potential threats. Hotels have always hosted the 'discrepant cosmopolitanisms' of tourists, diplomats, spies, protestors, labourers and vagabonds. Lastly, building designs and configurations are not security oriented. Many hotel buildings, particularly older ones, may not have been designed with security considerations in mind (e.g., no shatter-proof glass, no bomb-proof Kevlar wallpaper, not tamperresistant doors/windows).

2. Balancing security imperatives with guest satisfaction is difficult. Hoteliers find it awkward to maintain the highest possible standards of safety while preserving a hotel's hospitable and welcoming image (Hilliard and Baloglu, 2008; Enz, 2009; Homeland Security, 2010; Rittichainuwat, 2013; Ahmed, and Akther, 2013). Security may upset customers if it is deemed to be over-intrusive and an invasion of privacy so should be discreet, although an obvious presence can be a deterrent. A stringent increase in safety measures could frighten tourists because such measures could create a false perception that something untoward has previously happened at the destination. Hence, the old claim that stringent safety measures frighten tourists remains a classic rule of thumb.

3. Technology was expensive and always changing (Ahmed, and Akther, 2013). It was widely agreed that technology was an invaluable asset which could be used to detect dubious characters or harmful substances and deter terrorists. It was, therefore, important for hotels to be equipped with the latest technology and have the personnel to utilize it to optimal effect. However, technology was expensive and always changing. New technologies might not be compatible with those already in existence and installment could be a disruptive and costly operation, especially in older properties. Hotel security also could not rely on technology alone, even state-of-the-art, but depended on the aptitude of those manning it.

4. Many hoteliers did nothing to improve their safety and security systems, due to an "it can't happen here" mentality (Enz, 2003; Chan, 2004; Pizam 2010; Ahmed, and Akther, 2013; Chan, and Lam, 2013). Some hotel managers regarded security as a non-revenue-creating, non-productive expense and therefore did not see a need to improve their safety and security systems. Hence, security, if available, often ends up with the least amount of focus, attention and resources needed to adequately address the challenges and risks facing numerous organizations.

5. There is high turnover rate in security personnel which necessitates maintaining regular training for staff. Security department was understaffed and plagued with overtime issues (Homeland Security, 2010; Ahmed, and Akther, 2013; Farina, 2014). The dilemma was finding the right people for the job of security officer, given its long hours and relatively low pay. Retirees and the less educated usually formed the bulk of officers and they did not always display great physical fitness or the best mindset which was hard to instill. In addition, security is not the sole responsibility of the security staff; all hotel employees should emphasize and practice established security procedures and processes. Moreover, at the helm of the security department was a director of security, who himself was unlicensed and exhibited a militaristic disposition and non-customer service approach to dealing with the staff and guests.

In conclusion, due to hotels high vulnerability to threats and hazards, safety and security issues will remain a challenge for hotel firms for some period of time. This emphasizes that hotels should upgrade their safety and security measures and procedures to make them harder targets against threats and hazards. Hotel 
management has been forced to review and revise security measures accordingly. This puts increasing pressure on managers and planners concerned with hotels to develop more effective measures to stop or limit the severity of their negative impacts to protect hotel business and society in general (Pizam, 2010; Ghaderi, and Som, 2012; Mohammad et al., 2012; Nassar, 2012; AlBattat, and Som, 2013; Ahmed, and Akther, 2013; Peter, et al., 2014). The dramatic incidents associated with the Egyptian Revolutions from 2011 to date are recent reminders of the vulnerability of hotels to potential safety and security threats. It will be remembered for some time and perhaps lead to tourists putting a greater emphasis on personal safety and security when choosing accommodation in the future. It provides an opportunity to study safety and security measures from hotel guests' viewpoint.

\section{Need for Study}

Although available research on safety and security issues in the hospitality and tourism industry in general has been growing recently, studies on this matter in the hotel industry, in specific, are still limited. There are still only a few publications which discuss the concept systematically and holistically. No matter how far the existing literature has gone, there is a constant need to understand better safety and security issues and examine measures that can be used to stop or limit their negative impacts on a growing and important industry sector (Mansfeld and Pizam, 2006; Pizam, 2010; Boakye, 2012; Ahmed and Akther, 2013; Peter et al., 2014). Based on reviewing safety and security literature, a number of gaps have been identified:

1. The need for studying safety and security conceptualization. Due to the highly intangible nature of safety and security, there is no common body of terms or agreement on how and in what aspects safety and security are addressed. In this situation, searching for absolute, universal definitions is bound to fail. The extent of subjectivity in the issue needs to be reduced. Due to guests' growing safety and security concerns, a lack of conceptualization of hotel safety and security needs to be addressed (Hall et al., 2004; Piètre-Cambacédès, and Chaudet, 2010; Enz, 2009; Mekinc, and Cvikl, 2013; Yang, and Nair, 2013).

2. The need for studying safety and security measures in developing countries. While safety and security research has increased in recent years, relatively little has been written in emerging nations (African nations) (Boakye, 2012). Most of the research has occurred mostly in developed nations, most notably the United States. To fill this gap, Egypt as a developing country represents a unique setting for studying safety and security measures among hotel guests.

3. The need for studying safety and security measures in the hotel industry from guests' viewpoint. There is a lack of empirical research that investigates and evaluates the measures of safety and security from guests' viewpoint in the hotel industry in general and in Egyptian hotels in particular. The majority of past studies investigates safety and security issues and measures from hotel managers' viewpoint (E.g., Gill et al., 2002; Groenenboom and Jones, 2003; Hilliard and Baloglu, 2008; Enz, 2009; Pizam, 2010; Lisle, 2013; Peter et al., 2014). Useful though these studies might be, they are primarily anecdotal and do not provide an empirical understanding of hotel guests' security-related choices, perceptions, or needs. It may be difficult for hotels to install features that may improve security unless those features are commonly accepted by guests (Feickert, et al., 2006). Boakye, (2012) indicated that one way to provide security for tourists is to seek their own views on such matters. Studies which seek to do such are relatively underrepresented in the literature.

4. The need for studying the gap between the importance and usage of safety and security measures. While safety and security research has increased in recent years, very little studies have attempted to examine the gap between hotel guests' perceptions of the relative importance and performance of safety and security measures. It is logical, with an incorrect understanding of guest expectations and perceptions, hotel security managers would implement inappropriate security plans or provide relatively less important security measures. In turn, money may be wrongly invested in minor safety and security measures rather than those that are of major concern to most hotel guests, and safety and security measures that are rated as more important by hotel guests may be neglected or ignored by managers in designing those systems (Chan, and Lam, 2013). To provide high-quality services and a secure environment, it is important that managers understand the expectations and perceptions of their guests regarding the services and facilities provided. If not, managers might make a chain of bad decisions resulting in perceptions of poor hotel service quality (Zeithaml, et al., 1990). Understanding guests' perceptions of importance and performance toward safety and security measures is helpful in allowing managers to more effectively 
manage their safety budget (Rittichainuwat, 2013). This study fills this gap by measuring the gap between the importance and the actual usage level of safety and security measures from guest's viewpoint.

\section{Study Methodology}

\section{Importance-Performance Analysis (IPA) Method}

This study uses Multi-method data collection. The study objectives and its hypothesis revealed that this research study is primarily a descriptive-analytical study with qualitative and quantitative approaches. A combination of data collection methods provides a way to gain in- depth insights and adequately reliable statistics (Rittichainuwat, and Chakraborty, 2012). Using the Importance-Performance Analysis (IPA) methodology, this study examines the level of importance and level of performance (actual usage) of safety and security measures from hotel guests' viewpoint. IPA was developed by Martilla and James, (1977) as a popular managerial tool to facilitate prioritization of improvements and resource allocation. IPA assesses the convergence between the importance of specific attributes and how well a service provider is supplying those identified attributes. The main argument of the IPA model is that matching importance and performance (usage) is the basis of effective management. Typically, IPA involves a three-step process:

1. Identification of management-influenced attributes associated with a concept. This step is to identify the full complement of salient concept attributes. This is usually accomplished via consultation with experts, focus groups or other qualitative techniques.

2. Analysis of these attributes based on user data that rates attribute importance and performance.

3. Graphical presentation of the results. As shown in Figure 3, the interpretation of the IPA is graphically presented on a two- dimensional grid divided into four quadrants, based on the high or low importance on the y-axis and high or low performance (usage) on the x-axis (Beldona and Cobanoglu, 2007; Chen, 2014).

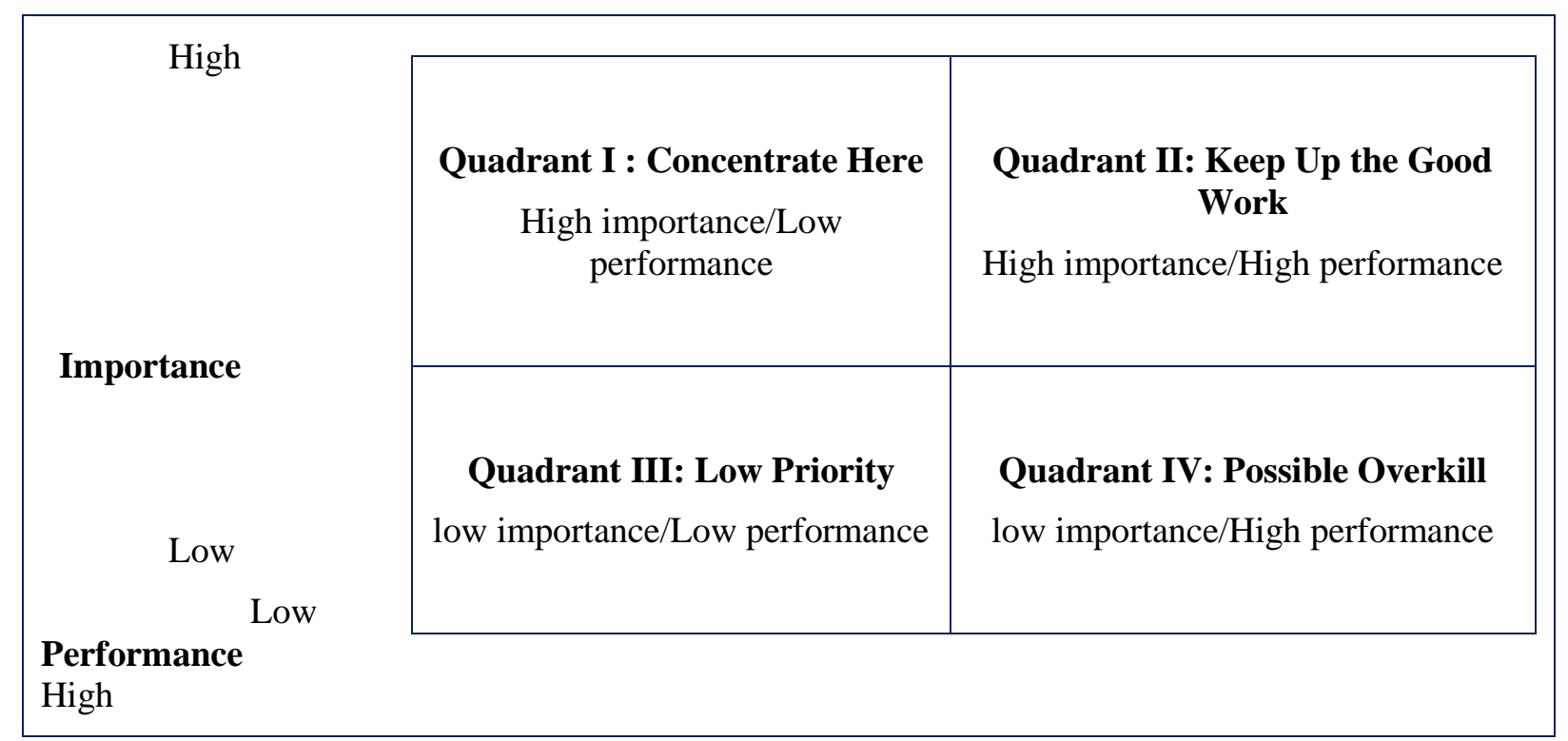

Figure 3: Importance-Performance Analysis Grid (Martilla and James, 1977; Beldona and Cobanoglu, 2007).

The decision to use the IPA structure and terminology was due to its relative simplicity and the fact that it was widely used and adopted in general managerial problems and also in the context of tourism and hospitality management (Israeli and Reichel, 2003;Israeli, 2007a,b; Beldona and Cobanoglu, 2007; Israeli, et al., 2011; Wong et 2011; Lopes, and Maia, 2012; Chen, 2014). IPA is a powerful evaluation tool for practitioners and academics to find out attributes that are doing well and attributes that need to be improved, which require actions immediately. In particular, there are two explicit advantages for hotel managers in applying IPA to their management know-how. First, IPA displayed graphically on a two-dimensional grid that explicitly shows the strengths and weaknesses of the hotel safety and security measures being studied. 
Second, IPA provides useful recommendations for hotel managers or policy makers for developing safety and security strategies and measures in the future. This is a useful and effective way for management to identify what problems exist, and why.

\section{Data Collection Instrument}

A written survey questionnaire was chosen as the primary method of quantitative data collection to measure safety and security measures through assessing the importance and performance (usage) level of practices. The questionnaire was developed based on two criteria:

A. The scale development procedures outlined by Hinkinet J al. (1997) for developing reliable and valid measurement instruments in any hospitality industry field research setting (Figure 4).

B. The Importance -Performance Analysis method (IPA) (Martilla and James, 1977) for evaluating the importance and usage level of security measures.

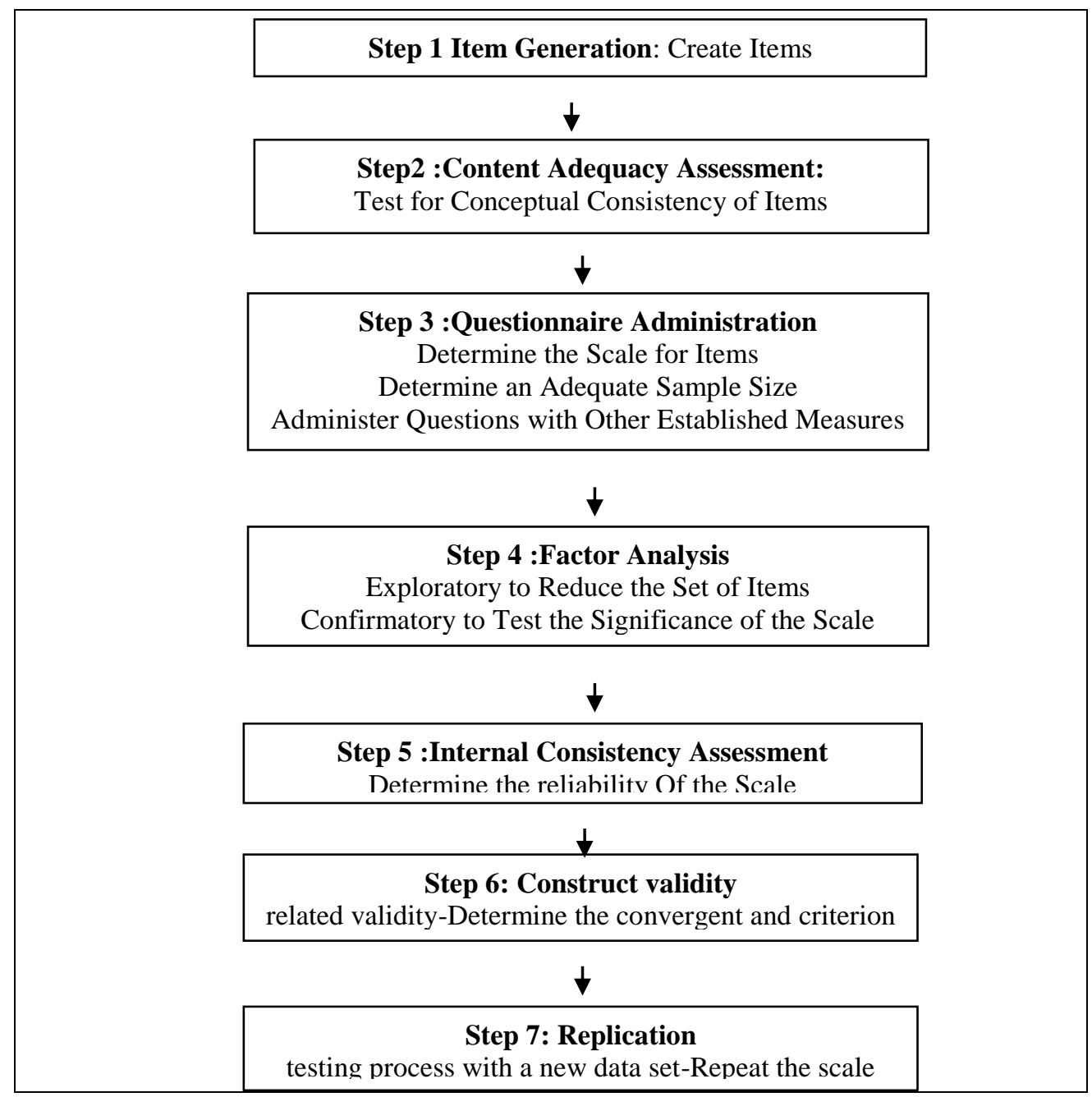

Figure 4: Guidelines for Scale Development and Analysis (Hinkin et al., 1997).

The first version of survey questionnaire was pilot tested using an appropriate number of hotel managers, guests, and academics to test the clarity of the content of the questionnaire and estimate of completion time. Revisions to the questionnaire were made based on feedback from the pilot test participants. The changes made the statements more specific and easier to understand. 50 measures representing 8 dimensions has finally identified in the questionnaire. The final instrument consisted of twoparts. The first examined the importance level guests assigned to each measure using a Likert scale of 1-least 
important to 5-most important. Additionally, this part examined the performance (usage) level for the same measure using a Likert scale ranging from 1-rarely used to 5-extensively used. The second part collected demographics. A cover letter in the message explained the purpose of the survey, due dates, contact information, and general directions.

\section{Sampling Plan and Procedures}

The target population of this study was the guests at five-star hotels in Egypt. Stratified random sample was chosen as the most appropriate sampling technique. Accordingly, Egypt was stratified geographically into 5 regions; Cairo, North West Coast, Canal Zone and Sinai, Red Sea, and Upper Egypt. As shown in Table 2, the percentage $30 \%$ was selected as the Sample of this study. The total selected number of hotels in the five regions was 47 hotels (representing $30 \%$ from total 157 -star hotels) (the Egyptian Hotel Guide 2010-2011).

Table 2: The Total Number \& Selected Percentage of Hotels in the Five Regions

\begin{tabular}{l|c|c|}
\hline \multirow{2}{*}{ Hotel Categories } & \multicolumn{2}{|c|}{ 5-star Hotels } \\
\cline { 2 - 3 } Egypt Regions & Total Population & $\begin{array}{r}\text { Sample } \\
(\mathbf{3 0 \%})\end{array}$ \\
\hline Cairo Region & 33 & 10 \\
\hline North West Coast Region & 14 & 4 \\
\hline Canal Zone \& Sinai Region & 55 & 16 \\
\hline Red Sea Region & 42 & 13 \\
\hline Upper Egypt Region & 13 & 4 \\
\hline Total & $\mathbf{1 5 7}$ & $\mathbf{4 7}$ \\
\hline
\end{tabular}

Source: The Egyptian Hotel Guide (2010-2011)

A guest who is staying at five-star hotels in the five regions of Egypt was asked to serve as respondents for the survey. A total of 500 questionnaires were randomly distributed to the guests in the hotel sample in January, 2015. From the sample, 300 questionnaires were returned, with a response rate of $60 \%$. Out of these 300 questionnaires, 25 were not included because of incompleteness. The valid number of questionnaires for analysis was 275 , and the response rate was $55 \%$. Privacy and confidentiality were critical to the success and integrity of the study. The use of Informed Consent was practiced. Additionally, each participant received a cover letter that reiterated the information in the Informed Consent form, but also stressed that participation in the study was voluntary. The respondents were advised that the data collected would be used solely for the purpose to address the research topic. There were no anticipated risks to the respondents who participated in the study.

\section{Data Analysis}

Data collected was entered into SPSS (version 19) data sheet and all analyses were performed. Study objectives and hypothesis were achieved by Descriptive Analysis, IPA matrix, and Paired T-test Analysis. Finally, interpretation of the results was done at $5 \%$ level of significance; where the value of $p \leq 0: 05$ was 
considered as being significant, and $\mathrm{p} \leq 0: 01$ was considered as being highly significant.

\section{Definition of Key Terms}

Safety and security measures refer to measures that are taken to protect the hotels, guests, and staff from danger or apprehension (threats or hazards). Measures include facilities, equipment, personnel, practices, and procedures designed to prevent or mitigate the effects of threats or hazards. The hotel guest is a person who stayed at a hotel for accommodation and hospitality services.

\section{Results and Discussion}

\section{Importance and Usage Assessment of Security Measures}

Table 3 and 4 indicate the safety and security measures' importance and usage assessment and analysis. The importance means scores of the 50 measures varied from 4.39 (the highest) to 3.16 (the lowest), with 1.0 indicating least important and 5.0 indicating most important. However, there was a distinction between the 50 measures and a priority of importance was evident. Meanwhile, the usage means scores of the 50 measures varied from 3.57 (the highest) to 2.45 (the lowest), with 1.0 indicating rarely used and 5.0 indicating extensively used. However, there was a distinction between the 50 measures and a priority of measures usage was evident. Overall, the average importance mean of measures was 3.86 , and the average usage mean of measures was 2.99 .

When evaluating measures' importance, Eighteen practices were perceived as most important with a mean greater than $4.20(\mathrm{M}>4.20$, on a 1 to 5 scale). It should be noted that these measures are related to three dimensions; "Medical Preparedness, Emergency Preparedness, and Guestroom Security". Hotel guests believed that these measures play a significant role in influencing their safety and security. This finding implied that hotel guests focus on these measures as the number one of priority. It is a guests' top priority in safety and security which should also be the priority of hoteliers. Hence, hotel operators should put in more effort and attention to improve these measures when managing safety and security. Twenty-one practices were perceived as important with a mean greater than 3.40 and less or equal to $4.20(4.20 \geq M>3.40$, on a 1 to 5 scale). It should be noted that these measures are related to three dimensions; "Staff Security, Access Control, and Information/Cyber security". This finding implied that hotel guests focus on these dimensions as the number two of priority. It is a guests' second top priority in safety and security management which should also be the second priority of hoteliers. Hence, hotel operators should put in more effort and attention to improve these measures when managing safety and security. 11 measures were perceived as moderately important with a mean greater than 2.60 and less or equal to $3.40(3.40 \geq \mathrm{M}>2.60)$. It should be noted that these measures are related to two dimensions; "Detectors, and Pool and Beach Security". Hotel guests considered these measures as the less important in safety and security management. They believed that these measures play a low significant role in influencing their safety and security. It is a guest's less priority which should also be the less priority of hoteliers. It should be noted, however, that these measures were also deemed important, but to a lesser extent and shouldn't be disregarded when managing safety and security.

When evaluating measures' usage, Fourteen measures were perceived as quite used with a mean greater than 3.40 and less or equal to $4.20(4.20 \geq \mathrm{M}>3.40)$. It should be noted that these measures are related to two dimensions; "Detectors, and Access Control". Hotel guests perceived these measures as the widely used action in safety and security. Hotel guests perceive these measures as the number one of usage priority. This finding implied that hotels' performance in applying these particular measures is strong. Thus, hotel managers ought to take them into consideration and continue to maintain a good standard and shouldn't be ignored. The top usage priority of Detectors and Access Control can be explained by the fact that the survey was conducted during the Egyptian political instability. One possible explanation is that detectors and access control measures are almost automatically considered when a new safety and security threats arise. 
Moreover, Detectors and Access Control measures are tangibles (high visible and noticeable) that invite guest concern. 5-star hotels invest significantly in detector measures and offer more features than do hotels in economy or budget segments in a resort or small town settings (Rittichainuwat, 2013). 21 measures were perceived as moderately used with a mean greater than 2.60 and less or equal to $3.40(3.40 \geq \mathrm{M}>2.60)$. It should be noted that these measures are related to three dimensions; "Staff Security, Information/Cyber security, and Pool/Beach Security". Hotel guests perceived these measures as the number two of usage priority. This finding implied that hotels' performance in applying these particular measures is moderate. Hence, hotel managers should concentrate on these practices and more resources, effort and attention should be spent on improving the performance of these measures. Fifteen measures were perceived as slightly used with a mean greater than 1.80 and less or equal to $2.60(2.60 \geq \mathrm{M}>1.80)$. It should be noted that these measures are related to three dimensions; "Medical Preparedness, Guestroom Security, and Emergency Preparedness". Hotel guests perceived these measures as the rarely used in safety and security management. Hotel guests perceived these measures as the less usage priority. This finding implied that hotels' performance in applying these particular measures is low. Hence, hotel managers should concentrate on these dimensions and more resources, effort and attention should be spent on improving the performance of these measures.

The rankings in descending order of the importance mean scores of 8 dimensions were as follow: Guestroom Security (4.27), Medical Preparedness, (4.24), Emergency Preparedness (4.22), Staff Security (3.91), Access Control (3.89), Information and cyber security (3.88), Pool and Beach Norms (3.26), and Detectors (3.22). Meanwhile, the rankings in descending order of the usage mean of 8 dimensions were as follow: Detectors (3.50), Access Control (3.46), Information and cyber security (3.30), Staff Security (3.02), Pool and Beach Norms (2.94), Guestroom Security (2.59), Emergency Preparedness (2.57), and Medical Preparedness (2.56). The results indicated that the less important and highly usage measures are related to Detectors dimension. While, the high important and rarely usage measures are related to Guestroom Security, and Medical Preparedness dimensions. 
Table (2): Measures" Importance and Usage Assessment

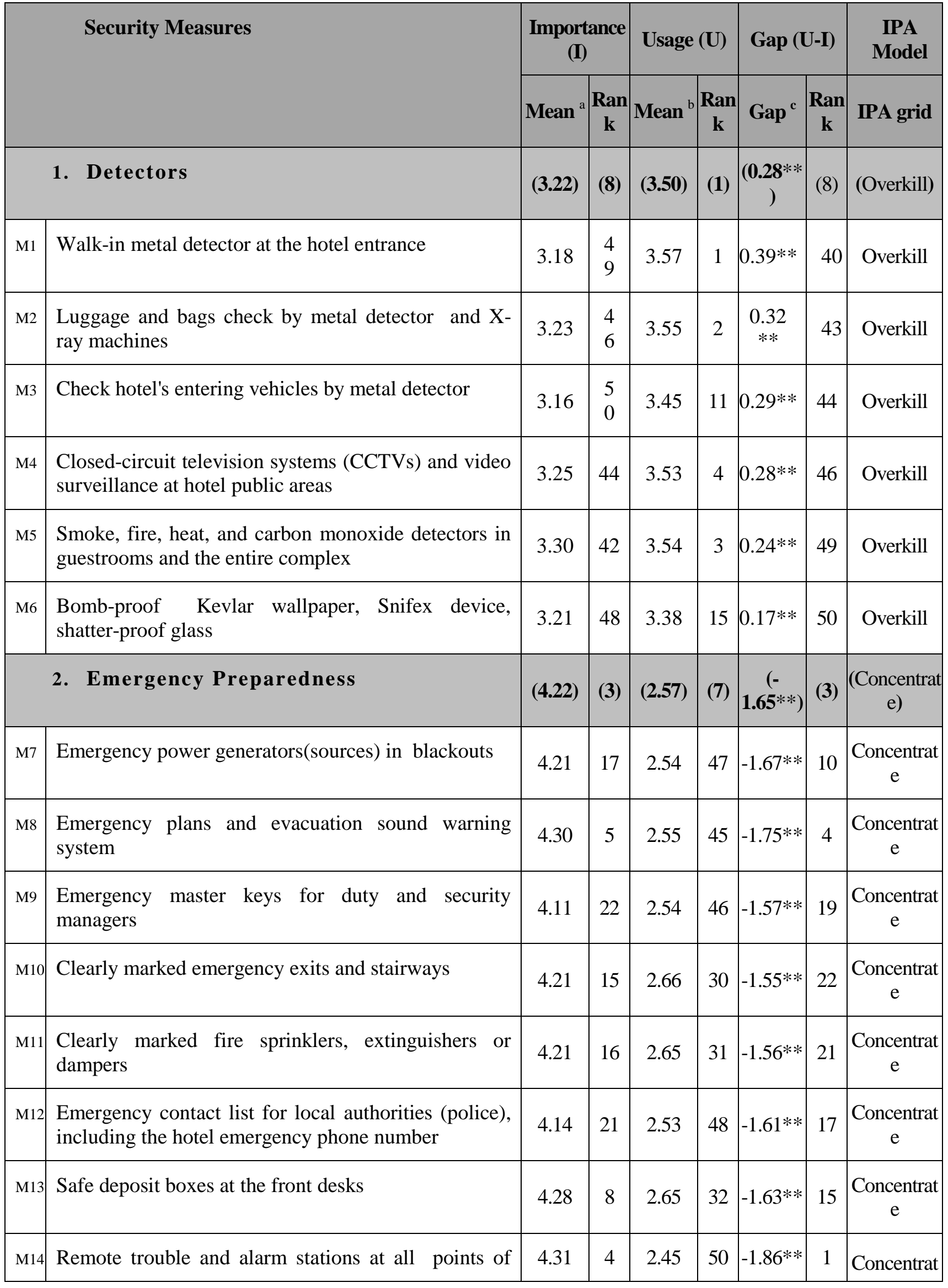




\begin{tabular}{|c|c|c|c|c|c|c|c|c|}
\hline & entry & & & & & & & $\mathrm{e}$ \\
\hline \multicolumn{2}{|r|}{ 3. Medical Preparedness } & (4.24) & (2) & (2.56) & (8) & $\begin{array}{c}(- \\
1.68 * *)\end{array}$ & (2) & $\begin{array}{c}\text { (Concentrat } \\
\text { e) }\end{array}$ \\
\hline M15 & A doctor on call 24 hours & 4.29 & 6 & 2.60 & 36 & $-1.69 * *$ & 8 & $\begin{array}{c}\text { Concentrat } \\
\mathrm{e}\end{array}$ \\
\hline M16 & A small clinic in the hotel & 4.26 & 9 & 2.58 & 40 & $-1.68 * *$ & 9 & $\begin{array}{c}\text { Concentrat } \\
\mathrm{e}\end{array} \mid$ \\
\hline M17 & A Pharmacy close to the hotel & 4.24 & 12 & 2.57 & 41 & $-1.67 * *$ & 11 & $\begin{array}{c}\text { Concentrat } \\
\mathrm{e}\end{array} \mid$ \\
\hline M18 & $\begin{array}{l}\text { Defibrillation Units: A life saving device in heart } \\
\text { attacks }\end{array}$ & 4.21 & 18 & 2.49 & 49 & $-1.72 * *$ & 6 & $\begin{array}{c}\text { Concentrat } \\
\mathrm{e}\end{array} \mid$ \\
\hline M19 & A face mask for each guest for smoke, disease & 4.23 & 13 & 2.56 & 42 & $-1.67 * *$ & 12 & $\begin{array}{c}\text { Concentrat } \\
\mathrm{e}\end{array}$ \\
\hline M20 & An ambulance or bed ambulance carrier & 4.23 & 14 & 2.56 & 43 & $-1.67 * *$ & 13 & $\begin{array}{c}\text { Concentrat } \\
\mathrm{e}\end{array}$ \\
\hline & 4. Staff Security & (3.91) & (4) & (3.02) & (4) & $\begin{array}{c}(- \\
\left.0.89^{* *}\right)\end{array}$ & (4) & $($ Keep Up) \\
\hline M21 & $\begin{array}{l}24 \text { Uniformed and non-uniformed security guards } \\
\text { carrying walkie-talkies }\end{array}$ & 3.89 & 32 & 3.09 & 21 & $-0.80^{* *}$ & 26 & Keep Up \\
\hline M22 & Security guards periodically patrolling the hotel & 3.89 & 31 & 3.07 & 22 & $-0.82 * *$ & 25 & Keep Up \\
\hline M23 & Security personnel with foreign language skills. & 3.95 & 23 & 2.95 & 26 & $-1.00 * *$ & 23 & $\begin{array}{c}\text { Concentrat } \\
\mathrm{e}\end{array}$ \\
\hline M24 & Staff knowledgeable about safety/security procedures & 3.92 & 26 & 2.98 & 25 & $-0.94 * *$ & 24 & $\begin{array}{c}\text { Concentrat } \\
\mathrm{e}\end{array}$ \\
\hline & 5. Guestroom Security & $(4.27)$ & (1) & (2.59) & (6) & $\begin{array}{c}(- \\
\left.1.68^{* *}\right)\end{array}$ & (1) & $\begin{array}{c}\text { (Concentrat } \\
\text { e) }\end{array}$ \\
\hline M25 & A first-aid kit in in each guest room & 4.39 & 1 & 2.56 & 45 & $-1.83^{* *}$ & 2 & $\begin{array}{c}\text { Concentrat } \\
\mathrm{e}\end{array}$ \\
\hline M26 & $\begin{array}{l}\text { In-room Secure deposit boxes to keep valuables (lap- } \\
\text { top) }\end{array}$ & 4.29 & 7 & 2.58 & 39 & $-1.71 * *$ & 7 & $\begin{array}{c}\text { Concentrat } \\
\mathrm{e}\end{array}$ \\
\hline M27 & $\begin{array}{l}\text { Door chains to allow the doors opened slightly to } \\
\text { view outside while still remaining locked }\end{array}$ & 4.25 & 10 & 2.61 & 35 & $-1.64 * *$ & 14 & $\begin{array}{c}\text { Concentrat } \\
\mathrm{e}\end{array}$ \\
\hline M28 & $\begin{array}{l}\text { Spy holes to allow residents to view clearly area of } \\
\text { outside without opening the door }\end{array}$ & 4.24 & 11 & 2.61 & 34 & $-1.63 * *$ & 16 & $\begin{array}{c}\text { Concentrat } \\
\mathrm{e}\end{array} \mid$ \\
\hline M29 & $\begin{array}{l}\text { Electronic key card-locking system (smart card, } \\
\text { optical, punch, biometrics and magnetic) on } \\
\text { guestroom doors }\end{array}$ & 4.35 & 2 & 2.62 & 33 & $-1.73 * *$ & 5 & $\begin{array}{c}\text { Concentrat } \\
\mathrm{e}\end{array}$ \\
\hline
\end{tabular}




\begin{tabular}{|c|c|c|c|c|c|c|c|c|}
\hline M30 & $\begin{array}{l}\text { Multilingual brochures to survive emergencies and } \\
\text { recommended guest safety/security precautions }\end{array}$ & 4.33 & 3 & 2.56 & 44 & $-1.77 * *$ & 3 & $\begin{array}{c}\text { Concentrat } \\
\mathrm{e}\end{array}$ \\
\hline M31 & A flash light in hotel rooms & 4.18 & 19 & 2.59 & 37 & $-1.59 * *$ & 18 & $\begin{array}{c}\text { Concentrat } \\
\mathrm{e}\end{array}$ \\
\hline M32 & Dedicated female-onlyguestfloor & 4.16 & 20 & 2.59 & 38 & $-1.57 * *$ & 20 & $\begin{array}{c}\text { Concentrat } \\
\mathrm{e}\end{array}$ \\
\hline & 6. Pool and Beach & $(3.26)$ & $(7)$ & $(2.94)$ & (5) & $\left(\begin{array}{c}(- \\
0.32 * *)\end{array}\right.$ & (7) & $\begin{array}{l}\text { (Low } \\
\text { Priority) }\end{array}$ \\
\hline M33 & Tsunami warning system on beaches & 3.30 & 40 & 2.87 & 29 & $-0.43 * *$ & 34 & $\begin{array}{l}\text { Low } \\
\text { Priority }\end{array}$ \\
\hline M34 & Lifeguards on the pool and beach for supervision & 3.30 & 41 & 2.94 & 27 & $-0.36 * *$ & 42 & $\begin{array}{l}\text { Low } \\
\text { Priority }\end{array}$ \\
\hline M35 & $\begin{array}{l}\text { Security boat surveillance(low noise pollution } \\
\text { engines) }\end{array}$ & 3.22 & 47 & 2.93 & 28 & $-0.29 * *$ & 45 & $\begin{array}{l}\text { Low } \\
\text { Priority }\end{array}$ \\
\hline M36 & $\begin{array}{l}\text { Secured fence and non-slip around the swimming } \\
\text { pool }\end{array}$ & 3.23 & 45 & 2.98 & 23 & $-0.25 * *$ & 48 & $\begin{array}{l}\text { Low } \\
\text { Priority }\end{array}$ \\
\hline M37 & $\begin{array}{l}\text { Safety signs as children should be supervised by an } \\
\text { adult }\end{array}$ & 3.25 & 43 & 2.98 & 24 & $-0.27 * *$ & 47 & $\begin{array}{l}\text { Low } \\
\text { Priority }\end{array}$ \\
\hline & 7. Access Control & $(3.89)$ & (5) & (3.46) & (2) & $\begin{array}{c}(- \\
\left.0.43^{*} *\right)\end{array}$ & (6) & (Keep Up) \\
\hline M38 & Limiting hotel main Access Points as possible & 3.85 & 39 & 3.48 & 6 & $-0.37 * *$ & 41 & Overkill \\
\hline M39 & $\begin{array}{l}\text { Physical and Hydraulically road barriers to prevent } \\
\text { close access by bombs or high-speed vehicles }\end{array}$ & 3.88 & 33 & 3.46 & 8 & $-0.42 * *$ & 35 & Keep Up \\
\hline M40 & $\begin{array}{l}\text { Sniffer dogs in hotel entrances and public areas } \\
\text { (parks) }\end{array}$ & 3.86 & 38 & 3.46 & 9 & $-0.40 * *$ & 39 & Keep Up \\
\hline M41 & $\begin{array}{l}\text { Key-activated elevators : Elevators interfaced with a } \\
\text { room electronic locking system }\end{array}$ & 3.94 & 24 & 3.44 & 14 & $-0.50 * *$ & 31 & Keep Up \\
\hline M42 & $\begin{array}{l}\text { Visitor management system: all visitor must be given } \\
\text { a 'visitor pass card'. }\end{array}$ & 3.88 & 34 & 3.47 & 7 & $-0.41 * *$ & 37 & Keep Up \\
\hline M43 & $\begin{array}{l}\text { Passport or photo ID check, especially for walk-in } \\
\text { guests at hotel check in }\end{array}$ & 3.89 & 30 & 3.45 & 12 & $-0.44 * *$ & 33 & Keep Up \\
\hline M44 & $\begin{array}{l}\text { Employees wearing a photo ID/nametag allowing } \\
\text { quick identification (Employee Verification) }\end{array}$ & 3.90 & 28 & 3.50 & 5 & $-0.40 * *$ & 38 & Keep Up \\
\hline M45 & $\begin{array}{l}\text { Trash management system by preventing bad } \\
\text { odor/diseases, hiding harmful/explosive substances, } \\
\text { and unauthorized access to discarded paper records }\end{array}$ & 3.88 & 35 & 3.46 & 10 & $-0.42 * *$ & 36 & Keep Up \\
\hline
\end{tabular}




\begin{tabular}{|c|l|c|c|c|c|c|c|c|}
\hline M46 & $\begin{array}{l}\text { The corridors and staircases are bright lighting and } \\
\text { wide enough for clients to prevent accidents }\end{array}$ & 3.93 & 25 & 3.44 & 13 & $-0.49^{* *}$ & 32 & Keep Up \\
\hline \multicolumn{2}{|c|}{ 8. Information and cyber security } & $(3.88)$ & $(6)$ & $(3.30)$ & $(3)$ & $\begin{array}{c}(- \\
\left.0.58^{* *}\right)\end{array}$ & $(5)$ & (Keep Up) \\
\hline M47 & $\begin{array}{l}\text { Pre-travel data surveillance and screening procedures } \\
\text { linked to check-in }\end{array}$ & 3.91 & 27 & 3.32 & 17 & $-0.59^{* *}$ & 28 & Keep Up \\
\hline M48 & $\begin{array}{l}\text { Install and maintain up-to-date cyber-security } \\
\text { techniques and software patches (firewalls, } \\
\text { virus/spyware protection, encryption, user } \\
\text { authentication). }\end{array}$ & 3.90 & 29 & 3.28 & 20 & $-0.62^{* * *}$ & 27 & Keep Up \\
\hline M49 & $\begin{array}{l}\text { Secure guest information (credit card number- } \\
\text { reservation information- registration card.........) }\end{array}$ & 3.86 & 36 & 3.30 & 18 & $-0.56^{* *}$ & 29 & Keep Up \\
\hline M50 & Caller screening by telephone operators & 3.86 & 37 & 3.30 & 19 & $-0.56^{* *}$ & 30 & Keep Up \\
\hline \multicolumn{1}{|c|}{ Total } & $\mathbf{( 3 . 8 6 )}$ & - & $\mathbf{( 2 . 9 9 )}$ & - & $\mathbf{0 . 8 7 * * )}$ & - & \\
\hline
\end{tabular}

${ }^{\mathrm{a}}$ Mean scale: 1 -least important to 5-most important. $\quad{ }^{\mathrm{b}}$ Mean scale: 1 - rarely used to 1 - extensively used. ${ }^{\mathrm{c}}$ Significant Difference: ${ }^{*} \mathrm{p} \leq 0.05 ; *{ }^{*} \mathrm{p} \leq 0.01$

Table 3: Measures"' Importance and Usage Analysis (Prioritizing)

\begin{tabular}{|c|c|c|c|c|c|}
\hline $\begin{array}{l}\text { Importance } \\
\text { scale }\end{array}$ & $\begin{array}{c}1 \\
\text { Least } \\
\text { important }\end{array}$ & $\begin{array}{c}2 \\
\text { Little } \\
\text { Important }\end{array}$ & $\begin{array}{c}3 \\
\text { Moderately } \\
\text { important }\end{array}$ & $\begin{array}{c}4 \\
\text { Important }\end{array}$ & $\begin{array}{c}5 \\
\text { Most } \\
\text { important }\end{array}$ \\
\hline Intervals & $1.00-1.80$ & $1.81-2.60$ & $2.61-3.40$ & $3.41-4.20$ & $4.21-5.00$ \\
\hline Measures & - & - & $\begin{array}{l}\quad 38 \text { measures } \\
2 \text { dimensions in } \\
\text { descending order: } \\
\text { - Pool and beach } \\
\text { norms } \\
\text { - Detectors }\end{array}$ & $\begin{array}{l}\quad 44 \text { measures } \\
3 \text { dimensions in } \\
\text { descending order: } \\
\text { - Information and } \\
\text { cyber security } \\
\text { - Staff security } \\
\text { - Access control }\end{array}$ & $\begin{array}{l}\quad 18 \text { measures } \\
3 \text { dimensions in } \\
\text { descending order: } \\
\text { - } \text { Medical } \\
\text { preparedness } \\
\text { - Guestroom security } \\
\text { - Emergency } \\
\text { preparedness } \\
\end{array}$ \\
\hline Usage Scale & $\begin{array}{c}1 \\
\text { Rarely used }\end{array}$ & $\begin{array}{c}2 \\
\text { Slightly used }\end{array}$ & $\begin{array}{c}3 \\
\text { Moderately used }\end{array}$ & $\begin{array}{c}4 \\
\text { Quite used }\end{array}$ & $\begin{array}{c}5 \\
\text { Extensively used }\end{array}$ \\
\hline Intervals & $1.00-1.80$ & $1.81-2.60$ & $2.61-3.40$ & $3.41-4.20$ & $4.21-5.00$ \\
\hline Measures & - & $\begin{array}{l}\text { 25 measures } \\
3 \text { dimensions in } \\
\text { descending order: } \\
\text { - Emergency } \\
\text { - } \text { preparedness } \\
\text { - } \text { Gedical preparedness } \\
\text { Guestroom security }\end{array}$ & $\begin{array}{l}45 \text { measures } \\
3 \text { dimensions in } \\
\text { descending order: } \\
\text { - Information and } \\
\text { cyber security } \\
\text { - Staff security } \\
\text { - Pool and beach }\end{array}$ & $\begin{array}{l}30 \text { measures } \\
2 \text { dimensions in } \\
\text { descending order: } \\
\text { - Detectors } \\
\text { - Access control }\end{array}$ & - \\
\hline
\end{tabular}


The Gap between the Importance and Usage of Measures

Table (2) indicates the mean gap score and rank order for each measure of safety and security. The mean gap scores for the 50 measures varied from $-1.86^{* *}$ (the highest gap) to $0.17^{* *}$ (the lowest gap). Nevertheless, each measure of security showed differences with respect to the size and direction of gap score. The mean gap scores for the 50 measures are all statistically significant (at $\mathrm{p}<0.01$ ). Overall, the average mean gap score was $-0.87 * *$. The average usage level of practices $(2.99)$ is lower than the average importance level (3.86).

The results of the paired t-test indicated a statistically significant difference (gap) $(p \leq 0.01)$ between the level of importance managers assigned to each measure and the level of usage of that measure. The mean gap between importance and usage for the 50 measures, are all statistically significant $(a t p<0.01)$. Hence, the null hypothesis which proposed an absence of difference was therefore rejected. Meanwhile, the alternate hypothesis which proposed an existence of difference was therefore accepted.

There are two observations. First, It should be noted that gaps are all significant, which suggests that at a basic level, there is a considerable difference between the measures' importance and usage. This finding implied that the hotels did not do a good job in matching measures' importance with measures' usage. There are opportunities for changes and improvement in Egyptian hotels. The existence of significant gaps clearly showed that there is a room for security management improvement in studied hotels. These gaps were the shortfalls and require the most attention by hotel managers in their efforts to make some improvement. By understanding and investigating those gaps. It is easier for management to control and take corrective action to reduce the difference between the importance and usage level of measures. The disparity between guests' perceptions of importance and actual performance of hotel safety and security measures may lead to guest dissatisfaction during hotel stays. Second, it should be noted that the majority of gaps are negative (in 44 measures, 7 dimensions), the usage level is lower than the importance level. A negative score indicated measures which should command more attention and that need to be improved. This finding implied that further improvement resources and efforts should concentrate here. Conversely, the few gaps are positive (in 6 measures, 1 dimension), the usage level is higher than the importance level. All positive measures are related to 'Detector' dimension. A positive score indicated measures which may be consuming too many resources and that need to be changed. This finding implied that present efforts and resources invested in these measures are over-utilized and therefore, hotel planners should consider allocating resources (i.e., money, time...) elsewhere, especially on the measures of negative gaps, to yield a higher return. The main argument of the IPA model is that matching importance and performance (usage) is the basis of effective management.

\section{Importance-Performance Analysis Matrix: IPA Grid}

Figure (4) shows the Importance-Performance Analysis Matrix for safety and security measures. Importance and performance (usage) mean scores of measures are plotted on a two- dimensional grid with importance on the $\mathrm{y}$-axis and usage on the $\mathrm{x}$-axis. The $\mathrm{Y}$-axis reports the hotel guests' perceived importance of measures, and the $\mathrm{X}$-axis shows the guests' usage in relation to these measures. In this particular matrix, the quadrants are separated by the average mean scores for importance and performance. The four identifiable quadrants are: 'Concentrate Here', 'Keep Up' the 'Good Work', 'Low Priority' and 'Possible Overkill'. Based on IPA positioning, hotels can determine which practices should command more attention and which may need many resources. The IPA matrix helps hotels to identify the areas for improvement and actions for minimizing the gap between importance and performance. Accordingly, the evaluating hotels should provide attention to items in the upper left quadrant, maintain services to those in the upper right, and consider reducing resources to those in the lower right. 


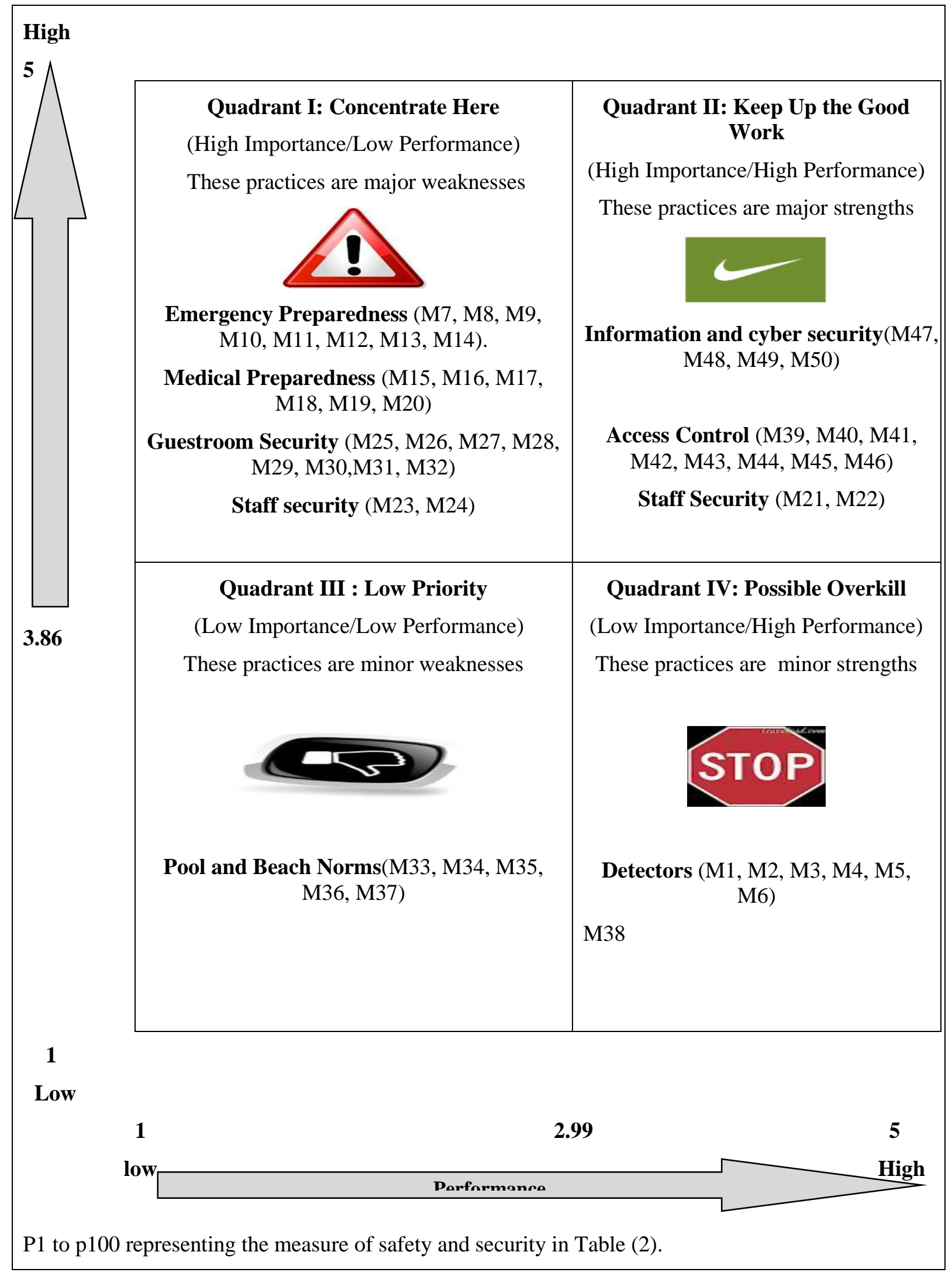

Figure 3: Applying Importance-Performance Grid for Security Measures 


\section{Conclusion and Recommendations}

Using IPA methodology, this study examines safety and security measures from hotel guests ' viewpoint, through assessing the importance and usage level of measures, and testing the gap between the importance and usage of measures. When evaluating the measures' importance, guests focused on "Medical Preparedness, Emergency Preparedness, and Guestroom Security". Meanwhile, when evaluating the measures' usage, guests focused on "Detectors, and Access Control". The results indicated that the highly important and rarely usage safety and security measures are related to three dimensions; "Medical Preparedness, Guestroom Security, and Emergency Preparedness". Meanwhile, the less important and widely usage/used measures are related to two dimensions; "Detectors, and Access Control". Additionally, there is a statistically significant gap between the importance level and the usage level of measures. Overall, the average usage level of measures (2.99) is lower than the average importance level (3.86). Hence, there are opportunities for changes and improvements in Egyptian hotels.

This research study contributes to the existing safety and security management literature by adding to the knowledge a theoretical model of safety and security measures, but more importantly, it also contributes to the hotel practice by adding to the knowledge a practical methodology by which hotel managers can assess and improve their level of safety and security measures. The study would enable hotel managers to determine which measure should require more attention and which may be consuming too many resources on achieving competitiveness' and effectiveness as a significant way for managing safety and security. Hoteliers can easily understand the areas where changes and improvements are needed. As noted in Figure (3), the results of IPA matrix provide useful recommendations for hotel managers or policy makers for improving and developing security management strategies and practices in the future. It provides insight for future management recommendations for each measure based on its position in one of the four quadrants. Each quadrant implies a different management strategy:

1. The studied hotels should command more attention and improvement efforts to 24 measures in the "concentrate here" quadrant (High Importance/Low Performance). These measures represent 3 dimensions; Guestroom Security, Medical Preparedness, and Emergency Preparedness. In addition 2 measures from Staff Security Dimension. These measures are major weaknesses and require immediate attention for improvement. It represents key areas that need to be improved with top priority. The management scheme for this quadrant is "concentrate here".

2. The studied hotels should maintain efforts and resources to 14 measures in the "keep up the good work" quadrant (High Importance/High Performance). These measures represent 2 dimensions; Information and Cyber Security, and Access Control. In addition 2 measures from Staff Security Dimension. These measures are major strengths and opportunities for achieving competitive advantage. Thus, hotel managers should keep up the good work in maintaining. The management scheme is "keep up the good work."

3. The studied hotels should not deserve remedial actions to 5 measures in the "low priority" quadrant (Low Importance/Low Performance). These measures represent 1 dimension; Pool and Beach Norms. These measures are minor weaknesses and do not require additional effort. Managers should not be overly concerned on these measures and should expend limited resources and efforts. The management scheme for this quadrant is "low priority."

4. The studied hotels should consider reducing resources and efforts to 7 measures in the "possible overkill" quadrant (Low Importance/High Performance). These 7 measures represent one dimension; Detectors. In addition 1 measure from Access Control Dimension. These measures are minor strengths. Hotel planners should overkill resources invested in these measures and therefore they should consider allocating resources (i.e., money, time) elsewhere, especially on those practices in the Concentrate Here quadrant. The management scheme for this quadrant is "possible overkill." 


\section{At a country level,}

- Meanwhile, at a political level, the current regime should take swift steps to end the political turmoil in Egypt.

- The short-term response by the government should be to exploit the media, particularly the international media, to emphasize the safety and the security of hotels and tourists.

- The government should also take serious steps in supporting the Ministry of Tourism in support of the recovery of the tourism and hotel industries, such as by coordinating with UNTWO to get the necessary support.

- Governments can assist hoteliers by offering support regarding safety training and by cutting taxes on imported technology and security equipment to increase safety and security in public areas.

- Government should decide that the security measures should be implemented within the premises of hotels in order to enhance the safety of tourists and should be imposed as conditions of the Tourist Enterprise License for hotels.

\section{Improving Safety and Security Culture and Awareness}

- Educating and reminding guests to attend to their safety and security via printed materials placed in guest rooms or at the front desk.

- Development of a Safety and Security Policy that includes the hotel's commitment to safety, and formally expresses objectives such as the principles and guidelines to follow in questions of safety and security at work.

- Increase security budgets. Security should be given a financial priority which reflects its importance. Investment in the recruitment of specialist staff, education and training of all staff and technology, in particular, will determine how well hotels respond to the safety and security threats.

- Hotel managers should keep abreast of incidents worldwide, learn from the shortcomings of others and take appropriate steps to reduce the chances of a similar occurrence in their property.

- The fight against security threats is also not only a matter for individual hotels and has to be dealt with collectively by the whole industry, governments, residents, and tourists. Communication, cooperation, and collaboration within the industry and with external stakeholders, and especially government agencies are also crucial to success in coping with security threats.

- Employees in general and security officers specifically should receive comprehensive training programs on governmental regulations, first-aid, fire and emergency evacuation to deal effectively with threats and hazards. Training should include security awareness and response plan Standard Operating Procedures (SOPs) that are to be used for different types of incidents.

- Sending staff to complimentary security training organized by hotel associations and local authorities need not be costly if training does not conflict with times of heavy workload.

- Training to improve the foreign language skills of security personnel is an important behavioral measure that is positively perceived as management's commitment to provide reasonable care to protect guests.

- Incentives for employee participation in health and safety activities, aimed at promoting safe behaviour, by means of punishments/rewards or by consulting them about their wellbeing in the workplace.

- Maintain up-to-date security training with regular refresher courses.

- Recruits also had to be cleared by the Egyptian Police Force, to confirm that they had no criminal record.

- Recruits (Security staff) had to be certified in carrying out medical procedures such as first-aid, cardiopulmonary resuscitation and automated external defibrillator rescue. 


\section{Future Research Recommendations}

Future research should examine the generalizability of these results. As technology improves and security features are expanded, additional research may be necessary to further validate these findings.

- Future studies can extend the same examination to other locations and other tourism and hotel sectors (e.g., airline, restaurant industries) to improve the robustness of the findings. This study serves as an impetus for additional studies in other nations and locations that will enhance the understanding of hotel safety and security measures and their effectiveness.

- This research can be extended to include broader types of hotels (e.g., 3, 4, and 5-star hotels) to test whether the guests' importance level and performance level of security measures will vary between types of hotels.

- It can be expanded to include a broader application of IPA for a comparison of safety and security measures for independent versus chain hotels, male versus female, leisure versus business, and 4-star versus 5 -star hotels. The aim is to test whether the perceived importance and performance of a hotel's security measures differ depending on these twin variables.

- Future research should identify and assess the primary motivators and barriers for implementing safety and security management.

- Future research studies should identify and examine the safety and security management knowledge and training necessary for hotel staff.

- Research is needed on the relationship between the levels of safety and security measures, and hotel's size, star rating, branding or nationality.

\section{Study Limitations}

The first limitation of this study is that it is limited to Egypt. The second limitation of this study was the sample population. The study findings are limited to the guests of 5-star hotels within five geographic regions of Egypt (Cairo, North West Coast, Canal Zone and Sinai, Red Sea, and Upper Egypt). Therefore, the findings cannot be generalized beyond this target population or to a broader population. A third limitation is that the safety and security measures used in this study do not represent all possible measures that may be taken. In addition, because of the wide variety of the types, sizes, and locations of hotels, not all suggested measures will be relevant or applicable. The measures in this guide are based on measures that owners and operators across the country have employed at their facilities. The ability to implement them at any specific facility will vary. The ideal number and structure of measures and dimensions could be different depending on the type of industry being studied, the service firm in question or the circumstances under which studies are rendered. A Final limitation was the potential for researcher bias. Additional research should focus on these potential limitations in order to assure the most precise results.

\section{Acknowledgement}

I thank Allah (God) for granting me the guidance, patience, health and determination to successfully accomplish this work. Acknowledgements are due to King Marriot institute for its support. I would like to consider security in more depth in a forthcoming special issue and would welcome any comments on how this might best be structured. 


\section{References}

Ahmed, S., and Akther, s. ( 2013), The threat of tourism industry in Bangladesh-a hotel industry prospective. Bangladesh Research Publications Journal, 8 (4): 204-210.

AlBattat, A.R., and Som, P.M. (2013), Emergency Preparedness for Disasters and Crises in the Hotel Industry. SAGE Open, July-September: 1-10.

Albrechtsen, E. (2003), Security vs safety. NTNU - Norwegian University of Science and Technology. Retrieved June 19, 2015 from http://www.iot.ntnu.no/users/albrecht/rapporter/notat\%20safety\%20v\%20security.pdf.

Boakye, K.A. (2012), Tourists' views on safety and vulnerability. A study of some selected towns in Ghana. Tourism Management, 33:327-333.

Beldona S., and Cobanoglu, C. (2007), Importance-performance analysis of guest technologies in the lodging industry. Cornell Hotel and Restaurant Administration Quarterly, 48 (3): 299-312.

Bentley, T.; Page, S., Meyer, D., Chalmers, D., and Laird, I. (2001), How safe is adventure tourism in New Zealand? An exploratory analysis, Applied Ergonomics, 32(4): 327-338.

Chan, E. (2004), An analysis of the gap in the perceptions of hotel marketing managers and business travelers regarding information technology facilities in hotel guestrooms in Hong Kong. Tourism Review International, 8 (1):17-31.

Chan, E. S.W., and Lam, D. (2013), Hotel safety and security systems: Bridging the gap between managers and guests. International Journal of Hospitality Management, 32: 202-216.

Chen, K.Y. (2014), Improving importance-performance analysis: The role of the zone of tolerance and competitor performance. The case of Taiwan's hot spring hotels. Tourism Management, 40: 260-272.

Enz, C.A. (2003), Changes in U.S. hotel safety and security staffing and procedures during 2001 and 2002. The CHR, Retrieved November 2, 2008 from: http://www.hotelschool.cornell.edu/chr/pdf/showpdf/chr/research/hotelsecurity.pdf.

Enz, C.A. (2009), The physical safety and security features of U.S. hotels. Cornell Hospitality Quarterly, 50 (4): 553-560.

Enz, C. A., and Taylor, M. S. (2002), The safety and security of U.S. hotels: A post September-11 report. Cornell Hotel and Restaurant Administration Quarterly, 43(5):119-136.

Farina, P. (2015), Security \& Safety. Does Luxury Equal Security?: A Tale of Two Properties. Retrieved June 19, 2014 from http://hotelexecutive.com/business review/2970/does-luxury-equalsecurity-a-tale-of-two-properties

Feickert, J.; Verma, R., Plaschka, G., and Dev, C.S.(2006).. Safeguarding your customers: the guest's view of hotel security. Cornell Hotel and Restaurant Administration Quarterly 47 (3): 224-244.

George, R. (2003), Tourist's perceptions of safety and security while visiting Cape Town. Tourism Management, 24 (5): 575-585.

Gill, M., Moon, C., Seaman, P., and Turbin, V. (2002), Security management and crime in hotels. International Journal of Contemporary Hospitality Management, 14 (2): 58-64.

Groeneboom, K., and Jones, P. (2003), Issues of security in hotels. International Journal of Contemporary Hospitality, 15(1): 14-19.

Ghaderi, Z., and Som, A. (2012), Penang's response to regional tourism crises: the crisis management approach. OIDA International Journal of Sustainable Development, 3 (10): 109-113. 
Hall, C.; Timothy, D., and Duval, D. (2004), Security and tourism: towards a new understanding? Journal of Travel \& Tourism Marketing, 15(2-3): 1-18.

Hinkin T.; Tracey, J., and Enz, C. (1997), Scale construction: developing reliable and valid measurement instruments. Journal of Hospitality and Travel Research, 21 (1): 100-119.

Homeland Security (2010), Protective Measures Guide for the U.S. Lodging Industry. American Hotel and Lodging Association.

Hilliard, T. W., and Baloglu., S. (2008), Safety and security as part of the hotel servicescape for meeting planners. Journal of Convention and Event Tourism 9 (1): 15-34.

Israeli, A. (2007a), Crisis management in the restaurant industry. International Journal of Hospitality Management, 26 (4): 807-823.

Israeli, A. (2007b), Effectiveness and efficiency of managers: are they doing what they can or all they can? Tourism Economics, 13 (2): 181-195.

Israeli A., and Reichel A. (2003), Hospitality crisis management practices: the Israeli case. International Journal of Hospitality Management, 22 (4): 353-372.

Israeli A.; Mohsin, A., and Kumar, B. (2011), Hospitality crisis management practices: The case of Indian luxury hotels. International Journal of Hospijtality Management, 30 (2): 367-374.

Kôvári, I., and Zimányi, K. (2011), Safety and security in the age of global tourism: the changing role and conception of safety and security in tourism. APSTRACT: Applied Studies in Agribusiness and Commerce, 5(3-4):59-61.

Line, M. B.; Nordland, O.; Røstad, and Tøndel,I. A. (2006), Safety vs. security? In M. G،. Stamatelatos, H.S., Blackman (Eds.) Proceedings of the 8th International Conference on Probabilistic Safety Assessment and Management (PSAM 2006), New Orleans, ISBN: 0791802442

Ling, G., and Zheng, X.M. (2008), Analysis on support ability of science and technology in hotel security. Journal of Beijing International Studies University, 05.

Lopes, S., and Maia, S. (2012), Applying importance-performance analysis to the management of health care services. China-USA Business Review, 11 (2): 275-282.

Lisle, D. (2013), Frontline leisure: Securitizing tourism in the War on Terror. Security Dialogue, 44(2): 127146.

Martilla, J., and James,J.(1977), Importance-performance analysis. Journal of Marketing, 41 (1): 77-79.

Maser, B., and Weiermair, K. (1998),Travel decision-making: from the vantage point of perceived risk and information preferences. Journal of Travel \& Tourism Marketing, 7(4), 107-121.

Mansfeld, Y., and Pizam, A. (2006),Toward a theory of tourism security. In Y. Mansfeld \& A. Pizam (Eds.), Tourism, security and safety: From theory to practice (pp.1-28). Burlington, MA: Elsevier, Butterworth-Heinemann.

Mekinc, J., and Cvikl, H. (2013), The Structure of security and safety crises in tourism. Journal of Tourism and Services, 4 (5-6): 38-50.

Milman, A.; Jones, F., and Bach, S., (1999), The impact of security devices on tourists' perceived safety: the central Florida example. Journal of Hospitality \& Tourism Research 23 (4): 371-386.

Mohammad, A.A.; Jones, E., Dawood, A.A., and Sayed, H.A. (2012), The Impact of the Egyptian political events during 2011 on hotel occupancy in Cairo. Journal of Tourism Research \& Hospitality, 1 (2): $1-8$.

Nassar, M.A. (2012), Political Unrest Costs Egyptian Tourism Dearly: An Ethnographical Study. International Business Research, 5 (10): 166-174.

Nardi, M. D., and Wilks, J. (2007),Tourist water safety: surf life saving initiatives for the Japanese inbound market, Journal of Vacation Marketing, 13(3): 275-283. 
Okumus, F. (2005). Safety. In: Pizam, A. (Ed.), International Encyclopedia of Hospitality Management. Elsevier Butterworth-Heinemann, Oxford.

Olsen, M. D. and Cassee, E. (1995), The international hotel industry into the new millennium: Visioning the future. Paris: International Hotel and Restaurant Association.

Olsen, M. D. and Pizam, A. (1999), Executive summary: a white paper from IH\&RA think tank on safety and security, Stockholm, Sweden. Paris: International Hotel and Restaurant Association.

Oxford Dictionaries (2015). Retrieved June 19, 2015 from http://www.oxforddictionaries.com/definition/english/safety http://www.oxforddictionaries.com/definition/english/security

Paraskevas, A. (2013), Aligning strategy to threat: A baseline anti-terrorism strategy for hotels. International Journal of Contemporary Hospitality Management, 25(1):140-162.

Parasuraman, A.; Zeithaml, V. A., and Berry, L. L. (1985), A conceptual model of service quality and its implications for future research. Journal of Marketing, 49(4), 41-50.

Prashyanusorna, V.; Kaviyaa, S., and Yupapinb, P. (2010), Surveillance system for sustainable tourism with safety and privacy Protection. Procedia Social and Behavioral Sciences, 2: 74-78.

Piètre-Cambacédès, L.; and Chaudet , C. (2010), The SEMA referential framework: Avoiding ambiguities in the terms "security" and "safety". International Journal of Critical Infrastructure protection, 3, 55-66.

Peter, C.; Poulston J., and Losekoot, E. (2014), Terrorism, rugby, and hospitality: She'll be right. Journal of Destination Marketing \& Management, 3: 253-261.

Pizam, A. (1999), A comprehensive approach to classifying acts of crime and violence at tourism destinations. Journal of Travel Research, 38 (1):5-12.

Pizam, A. (2010), Hotels as tempting targets for terrorism attacks. International Journal of Hospitality Management, 29 (1): 1.

Sönmez, S. F., and Graefe, A. R. (1998a), Determining future travel behavior from past travel experience and perceptions of risk and safety. Journal of Travel Research, 37(2): 172-177.

Sönmez, S., and Graefe, A. R. (1998b), Influence of terrorism risk on foreign tourism decisions. Annals of Tourism Research, 25(1), 112-144.

Sonmez, S.; Apostolopoulos, Y., \& Tarlow, P. (1999), Terrorism in crisis: Managing the effects of terrorism. Journal of Travel Research, 38(4):13-18.

Su, X.W. (2009), Discussion in the hotel emergencies emergency management. Science Technology and Industry, 12.

Reisinger, Y., and Mavondo, F. (2005), Travel anxiety and intentions to travel internationally: implications of travel risk perception. Journal of Travel Research, 43(3): 212-225.

Rittichainuwat BN.(2006), Tsunami recovery: a case study of Thailand's tourism. Cornell Hotel Restaur Adm Q, 47(4):390-404.

Rittichainuwat NB(2008), Responding to disaster, The Case Study of Phuket, Thailand. Journal of Travel Research, 46(4):422-32.

Rittichainuwat, N.B. (2011), Ghosts: A travel barrier to tourism recovery. Annals of Tourism Research, 38(2): 437-459.

Rittichainuwat, B.N. (2013), Tourists' Perceived Risks Toward Overt Safety Measures. Journal of Hospitality \& Tourism Research, 37(2):199-213.

Rittichainuwat, B.N.; and Chakraborty, G. (2012), Perceptions of importance and what safety is enough. Journal of Business Research 65: 42-50.

Taillon, G.M. (2012), A Book Review: Security and Everyday Life. e-Review of Tourism Research (eRTR),10 (3):1-3. http://ertr.tamu.edu/ 
Tarlow, P.E., and Santana, G. (2002), Providing safety for tourists: a study of a selected sample of tourist destinations in the United States and Brazil. Journal of Travel Research, 40 (4): 424-431.

The Egyptian Hotel Guide (2010-2011), 31 ${ }^{\text {st }}$ Edition. Egyptian Hotel association.

Yang, E.C.L. and Nair, V. (2014), Tourism at risk: A review of risk and perceived risk in tourism. AsiaPacific Journal of Innovation in Hospitality and Tourism, 3(2): 239-259.

Wichasin, P., and Doungphummes, N. (2012), A comparative study of international tourists' safety needs and Thai tourist polices' perception towards international tourists' safety needs. World Academy of Science, Engineering and Technology, 67, 1372-1378. International Scholarly and Scientific Research \& Innovation 6(7):1163-1169.

Wong, M.; Hideki, N., and George, P. (2011), The Use of Importance-Performance Analysis (IPA) in Evaluating Japan's E-government Services. Journal of Theoretical and Applied Electronic Commerce Research, 6 (2): 17-30.

World Tourism Organization. (WTO) (2012), UNWTO Tourism Highlights. 2012 Edition. Retried February 25, 2012 from www.unwto.org/facts

World Travel and Tourism Council (WTTC) (2013), Travel and Tourism Economic impact 2013, World. The Authority on World Travel and Tourism. Retrieved June 19, 2013 from http://www.wttc.org/site_media/uploads/downloads/world2013_1.pdf

Egyptian Ministry of Tourism (2011), Reports of hotels occupancy rates. Cairo: Sector of hotels and resorts.

Zeithaml, V.A.; Parasuraman, A. and Berry, L.L. (1990), Delivering quality service: Balancing customer perceptions and expectations, New York, NY: The Free Press. 


\section{تدابير السلامة والأمن في الفنادق المصرية \\ كرم منصور غازي}

المعهد العالي للسياحة والفنادق، كينج ماريوت، الإسكندرية، مصر.

ملخص

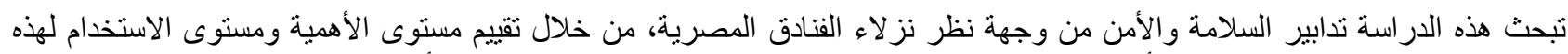

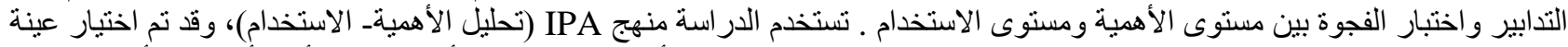

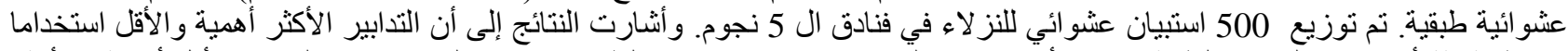

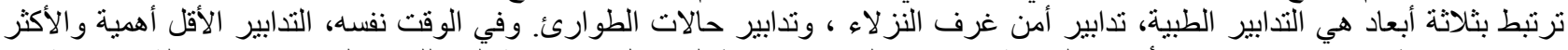

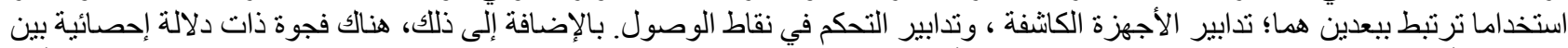

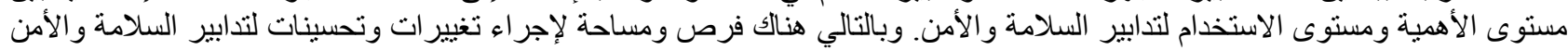
في الفنادق المصرية.

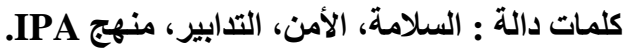

